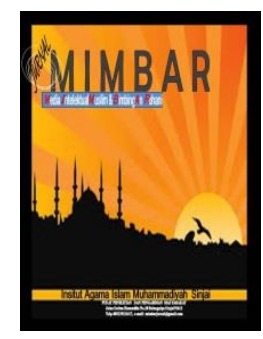

\title{
MIMBAR
}

Jurnal Media Intelektual Muslim dan Bimbingan Rohani

Volume 5, No. 2, 2019

ISSN (print) : 2442-3217

ISSN (online) : 2716-3806

Homepage : http://journal.iaimsinjai.ac.id/indeks.php/mimbar

\section{PEMIKIRAN POLITIK ERA KENABIAN, SAHABAT DAN SEKTE- SEKTE ISLAM: TINJAUAN SKETSA HISTORISITAS}

\section{Umar $^{1}$}

Institut Agama Islam Muhammadiyah Sinjai

Email: oemar.beksam@yahoo.com

\begin{abstract}
Abstrak
Dalam sejarah perkembangan Islam dari era kenabian hingga pada kekhalifahan khulafa Al-Rasyidun tidak lepas dari system politik, baik dalam bentuk penyebaran agama Islam maupun dalam pemerintahan. Pemikiran politik Islam diawali oleh sejak penyebaran agama Islam, namun dalam perkembangannya mengalami dinamika yang kompleks terutama dalam masa pemerintahan pemimpin-pemimpin Islam pasca Nabi (Khulafa Al-Rasyidun), gejolak politik yang dihadapi umat Islam oleh pemimpin Islam dengan karakter yang berbeda-beda menorehkan peta konflik yang cenderung melahirkan teori politik yang berbeda pula. Dalam tinjauan secara umum sejarah politik Islam dari era kenabian, sahabat dan sekte-sekte Islam ini mengemukakan sketsa perpolitikan yang patut direnungi dan dengan melihat asas kesatuan politik masa kini sebagai bahan perbandingan, bahwa sejarah politik Islam mengalami transisi dan evolusi seiring dengan perkembangan dan dinamika suatu masyarakat. Pada tulisan ini mengemukakan sketsa historisitas perpolitikan Islam dan era kenabian, sahabat dan sekte-sekte Islam sehingga turut mempengaruhi eksistensi Islam masa kini.
\end{abstract}

Kata Kunci: Historis, Pemikiran politik, Era Nabi, Sahabat dan Sekte Islam.

${ }^{1}$ Dosen pada STAI Muhammadiyah Sinjai 


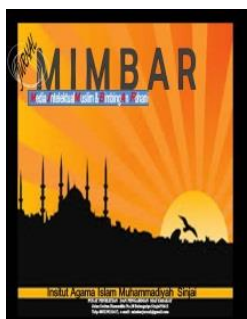

MIMBAR

Jurnal Media Intelektual Muslim dan Bimbingan Rohani

Volume 5, No. 2, 2019

ISSN (print) : 2442-3217

ISSN (online) : 2716-3806

Homepage : http://journal.iaimsinjai.ac.id/indeks.php/mimbar

\section{A. Pendahuluan}

Salah satu pendekatan yang digunakan dalam pengkajian Islam dan pendidikan Islam khususnya adalah melalui pendekatan ( politik $^{2}$ )-“Pemikiran politik ${ }^{3}$ Islam”, atau dengan kata lain pengkajian politik dalam Islam ${ }^{4}$. Hal ini penting menjadi bahan kajian akademisi dalam studi orientasi pendidikan khususnya pendidikan Islam. Selain metodologi, tradisi historis-empirisme, dan filsafat mendapat porsi dalam melakukan pengkajian ini.

Perdebatan saat ini tentang kebangkitan umat Islam telah menyebabkan masalahmasalah yang berkaitan dengan hakikat, karakteristik, serta ruang lingkup suatu negara Islam dan system politik Islam yang khas, mendapat sorotan tajam. Banyak penerbitan mengenai masalah itu yang implikasi-implikasi ideologis dan posisi teoritisnya yang beragam. Tetapi kebanyakan hanya menyajikan peristiwa-peristiwa politik mutakhir di dunia Islam kontemporer tanpa ada upaya untuk membahas aspek-aspek teori politik yang benar-benar dapat mempengaruhi peristiwa-peristiwa tersebut. Bahkan uraian mereka tentang dunia politik masa kini tetap dangkal dan tidak bertalian dengan keteganganketegangan antara perlunya kesinambungan dan tuntutan akan perubahan di dunia Islam. ${ }^{5}$

${ }^{2}$ Menurut Deliar Noer dalam Abdul Muin Salim bahwa politik adalah segala aktivitas yang berhubungan dengan kekuasaan dan yang bermaksud untuk mempengaruhi, dengan jalan mengubah atau mempertahankan, suatu macam bentuk susunan masyarakat. Abdul Muin Salim, Fiqh Siyasah, Konsepsi Kekuasaan Politik dalam Al-Qur'an, (Jakarta: Raja Grafindo Persada, 2002), hlm. 37.

${ }^{3}$ Mengkaji segi kekuasaan; bagaimana sampai kepada kekuasaan itu (baik secara sukarela maupun dengan paksaan kekuatan)? Bagaimana mengaturnya? Bagaimana hubungan individu dengan kekuasaan itu (apakah mundur, keluar, atau berinteraksi)?. Ia juga mengkaji masalah "Undang-Undang Dasar" yang mengatur hubungan-hubungan keorganisasian antara lembaga-lembaga kekuasaan politik (eksekutif), legislative, dan yudikatif (bentuk negara secara hukum), dan mengkaji segi proses "saling mempengaruhi antara lembaga-lembaga kekuasaan yang berkuasa dan aliran-aliran pemikiran yang bergerak di tengah masyarakat (partai, opini umum, perwakilan dan kepemilikan). Lihat Tijani Abdul Qadir Hamid, Pemikiran Politik dalam Al-Qur'an, Terj. Abu Hayyi Al-Kattani, (Jakarta: Gema Insani Press), 2001, hlm. 4.

${ }^{4}$ Dalam bahasa agamanya disebut Fiqh Siyasah dalam konteks terjemahan diartikan sebagai materi yang membahas mengenai ketatanegaraan Islam (Politik Islam). Secara bahasa Fiqh adalah mengetahui hukum-hukum Islam yang bersifat amali melalui dalil-dalil yang terperinci. Sedangkan Siyasah adalah pemerintahan, pengambilan keputusan, pembuatan kebijaksanaan, pengurusan, dan pengawasan. Alfajri Asbahri, dkk, Teori Politik Islam, dalam pdf. (Bandung: Institut Tekhnologi Bandung, 2011), hlm.11.

${ }^{5}$ Kegagalan literatur masa kini yang berkaitan dengan Islam dan politik, yang secara teori peduli dan peka terhadap masalah-masalah yang besar yang senantiasa timbul yang mendasari basis normatif dan praktek pemerintah, sebagian besar disebabkan oleh tidak memadainya disiplin itu sendiri. Ilmu politik modern telah mendefinisikan sedemikian sempit sehingga kehilangan kaitannya dengan aspek-aspek lain dari upaya-upaya kolektif kehidupan manusia. Mumtaz Ahmad, Masalah-Masalah Teori Politik Islam, (Bandung: Penerbit Mizan, 1996), hlm. 13. 


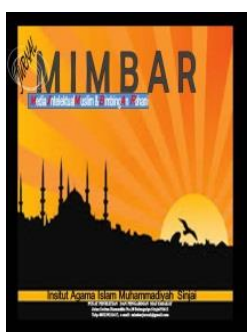

Jurnal Media Intelektual Muslim dan Bimbingan Rohani

Volume 5, No. 2, 2019

ISSN (print) : 2442-3217

ISSN (online) : 2716-3806

Homepage : http://journal.iaimsinjai.ac.id/indeks.php/mimbar

Oleh karena itu pentingnya melirik sejarah politik-teori politik Islam sejak era kenabian Muhammad SAW sebagai starting point dalam melakukan perbandingan perpolitikan masa kini.

Islam sebagai agama yang fundamental didalamnya tidak hanya termuat system yang mengatur hubungan antara seseorang dengan rabb-Nya, urusan-urusan yang dinamakan keduniaan (materi), peperangan, harta dan lain-lain. Agama, khususnya Islam didalamnya pun termuat system yang dinamakan sistem politik. Politik Islam yang telah ada dan dipraktekkan Rasulullah dan khulafa al-rasyidin dan sepanjang sejarahnya, hingga para intelektual muslim masa kini perlu dilakukan pengkajian secara orientasi dan teoritis.

Secara historis lahirnya teori politik Islam dimana Rasullullah SAW sebagai seorang pencetus yang bijaksana sekaligus negarawan. Kita ketahui bahwa terdapat dua fase kehidupan Rasulullah SAW yaitu, pertama, fase Mekkah (awal mula lahir dan tumbuhnya ajaran Islam) dan. kedua, fase Madinah, yakni perkembangan Islam mengalami kemajuan ditandai dengan berdirinya negara Madinah yang solid, (kota pusat pemerintahan dan penyebaran Islam). Pada fase inilah politik Islam telah ditorehkan melalui tintah sejarah yang banyak berpengaruh, meskipun ditiap negara memiliki sistem politik yang berbeda, Islam sebagai agama yang lahir membawa perubahan sosial yang cukup dalam tiap dimensi kehidupan masyarakat, baik dari segi politik hal ini menyebabkan karena aturan politik Islam pada dasarnya membawa negara dan masyarakatnya adil dan sejahtera. Meskipun dalam kitab suci Al-Qur'an tidak dijelaskan aturan politik, tetapi era kenabian (zaman Rasulullah SAW) telah menjadi bukti sejarah terutama pada fase Madinah, betapa adilnya sebuah pemerintahan dibawa politik Islam hal ini dikarenakan masyarakat komitmen menjalankan syariat Islam.

Potret perkembangan suatu negera Islam tidak lepas dari Islam dan politik, selalu menjadi topik pembahasan sepanjang sejarah Islam hingga era kontemporer masa kini. Kaitan ini Montgomery Watt memberikan tinjauan bahwa secara keseluruhan, dalam batas-batas perkembangan sejarah dunia, terlihat bahwa agama mempunyai keterkaitan yang erat dengan politik. Alasan untuk itu tidak perlu terlalu jauh dicari. Apabila politik telah menjadi sesuatu yang serius, yang menyebabkan seseorang bersedia mati untuk 


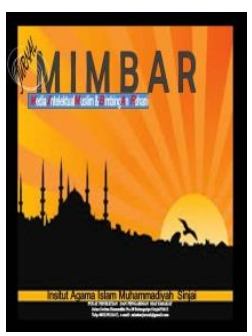

Jurnal Media Intelektual Muslim dan Bimbingan Rohani

Volume 5, No. 2, 2019

ISSN (print) : 2442-3217

ISSN (online) : 2716-3806

Homepage : http://journal.iaimsinjai.ac.id/indeks.php/mimbar

membelanya, tentu ada tenaga pendorong yang melandasi perilaku kehidupan yang demikian. ${ }^{6}$

Atas pandangan tersebut tulisan ini membahas historisitas tentang lahirnya pemikiran politik atau teori-teori politik ketika era kenabian, era pemerintahan sahabat dan beberapa teori politik dari sekte-sekte Islam. Pembahasan ini memunculkan dua perumusan masalah pokok yang dijelaskan selanjutnya yaitu; (1) Proses pembentukan negara Islam ketika era kenabian, (2) Teori-teori Islam yang ini lahir. melalui tinjauan historisitas umum berikut tentunya tulisan ini diharapkan memberikan informasi dalam khazanah keilmuan.

\section{B. Pembentukan Negara Islam dan Era Kenabian}

Era kenabian merupakan era dimana ketika Nabi Muhammad SAW hidup yang membawa ajaran Islam dan memulai dakwah kepada manusia untuk menyembah Allah SWT hingga wafat. Kesempurnaan era kenabian tersebut merupakan ciri utama yang nampak dan membawa perubahan sosial pada masyarakat Arab umumnya. Era kenabian tercatat dalam literatur-literatur sejarah terbagi menjadi dua fase sebagaimana dijelaskan diawal.

Dalam sejarah Nabi Muhammad SAW sejak awal penyebaran Islam di kota Mekah dengan melakukan penyebaran Islam secara sembunyi-sembunyi hingga secara terangterangan yang mengalami tekanan, intimidasi dan konspirasi dari kalangan kafir Quraisy hingga melakukan hijrah ke kota Madinah. Penduduk Yastrib (Madinah) menerima Nabi dengan resmi dan menjadikannya sebagai pemimpin bagi penduduk tersebut. Disinilah babak baru dalam sejarah Islam dimulai dengan didirikannya negara Islam pertama dan pusat pemerintahan yang unggul, satu-satunya kepemimpinan dalam Islam sepanjang

\footnotetext{
${ }^{6}$ Lebih lanjut menurutnya biasanya tenaga seperti itu hanya bisa ditimbulkan oleh agama, atau oleh suatu ideology yang memiliki beberapa fungsi agama (misalnya, menjadikan seseorang sadar kepada siapa kehidupannya digantungkan), Lihat W.Montgomery Watt, Politik Islam dalam Lintasan Sejarah, terj. Helmy Ali, Muntaha Azhari, (Jakarta: Perhimpunan Pengembangan Pesantren dan Masyarakat (P3), 1988), hlm. 1 .
} 


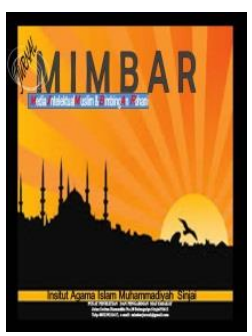

Jurnal Media Intelektual Muslim dan Bimbingan Rohani

Volume 5, No. 2, 2019

ISSN (print) : 2442-3217

ISSN (online) : 2716-3806

Homepage : http://journal.iaimsinjai.ac.id/indeks.php/mimbar

sejarah dengan system politik Islam yang tunggal dengan syariat Islam dan tak ada persamaan kepemimpinan manapun.

Di kota Madina, Islam merupakan kekuatan politik. Ajaran Islam yang berkenaan dengan kehidupan masyarakat banyak turun di Madinah. Nabi Muhammad SAW mempunyai kedudukan, bukan saja sebagai kepala negara, dengan kata lain dalam diri Nabi terkumpul dua kekuasaan, kekuasaan spiritual dan kekuasaan duniawi. Kedudukan sebagai Rasul secara otomatis merupakan sebagai kepala negara. Dalam rangka memperkokoh masyarakat dan negara baru itu, ia segera meletakkan dasar-dasar kehidupan bermasyarakat yaitu ${ }^{7}$; Dasar pertama yaitu pembangunan masjid, selain tempat shalat, juga sebagai sarana penting untuk mempersatukan kaum muslimin dan mempertalikan jiwa mereka, disamping sebagai tempat bermusyawarah juga berfungsi sebagai pusat pemerintahan. Dasar kedua, adalah ukhuwwah islamiyah, persaudaraan sesama muslim. Nabi mempersaudarakan antara golongan Muhajirin (orang-orang yang hijrah dari Mekah ke Madinah) dan Anshar, penduduk Madinah yang telah masuk Islam dan ikut membantu kaum Muhajirin tersebut. Dasar ketiga, hubungan persahabatan dengan pihak-pihak lain yang tidak beragama Islam. Di Madinah, disamping orang Arab Islam, juga terdapat golongan masyarakat Yahudi dan orang-orang Arab yang masih menganut agama nenek moyang mereka.

Dalam rangka mewujudkan kestabilan masyarakat dan pemerintahan Nabi mengadakan perjanjian dengan seluruh penduduk Madinah yang melahirkan "Piagam Madinah" yaitu suatu perjanjian yang memberikan jaminan kebebasan beragama ditiap komunitas, dan memiliki hak tertentu dalam politik dan keagamaan. Sebagai kepala pemerintahan diberikan wewenang dan otoritas mutlak dalam menjalankan kepemimpinannya. Kepemimpinan yang diembangnya dengan misi masyarakat madani pun terwujud hanya dalam beberapa tahun. Hal ini membuktikan bahwa era kepemimpinan Rasul dengan politik yang diterapkannya merupakan ciri pemerintahan yang penuh dengan kearifan.

\footnotetext{
${ }^{7}$ Badri Yatim, Sejarah Peradaban Islam, (Jakarta: PT Raja Grafindo Persada, 1998), hlm. 25-26
} 


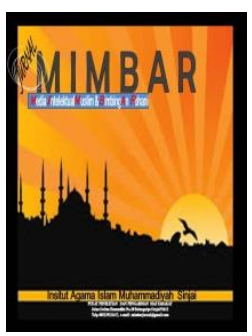

\section{MIMBAR}

Jurnal Media Intelektual Muslim dan Bimbingan Rohani

Volume 5, No. 2, 2019

ISSN (print) : 2442-3217

ISSN (online) : 2716-3806

Homepage : http://journal.iaimsinjai.ac.id/indeks.php/mimbar

Dalam bidang sosial, Nabi juga meletakkan dasar persamaan antar sesama manusia. Perjanjian ini, dalam pandangan ketatanegaraan sekarang, sering disebut dengan Konstitusi Madinah. Dengan terbentuknya negara Madinah, Islam makin bertambah kuat, Sebagai kepala pemerintahan selalu dihadapkan berbagai gangguan musuh, maka Nabi mengatur siasat dan membentuk pasukan tentara. Ada dua alasan umat Islam diizinkan berperang yaitu, pertama, untuk mempertahankan diri dan melindungi hak-haknya, kedua menjaga keselamatan dan penyebaran kepercayaan dan mempertahankannya dari orangorang yang menghalanginya. ${ }^{8}$

Selama kira-kira sepuluh tahun di Madinah (622-32), Muhammad mengkonsolidasikan kontrol beliau atas masyarakat kota yang beragama, dan beliau memperluas kekuasaan dan pengaruh Madinah di Arab. ${ }^{9}$ Maka puncak keemasan Islam telah mewarnai kehidupan bangsa Arab pada masanya. Jika periode Madinah terdapat negara Islam, maka periode Mekah telah menanamkan keyakinan atau akidah yang menjadi dasar atau asas suatu negara. ${ }^{10}$ Suatu kepastian pada masa yang panjang ini merupakan masa pembelajaran iman, melunakkan kekerasan, sabar, kegigihan, dan pengorbanan yang diasuh langsung oleh pemimpin Islam. Eksistensi nilai-nilai inilah yang harus dipertahankan dalam sebuah negara. ${ }^{11}$ Menurut Husaini yang dikutip oleh Abdul Karim, negara dan pemerintahan Madinah adalah bercorak teokrasi yang dikepalai oleh seorang Rasul yakni Muhammad dan ia adalah pemimpin agama. Ia membuat undangundang atas dasar Al-Qur'an. Walaupun nabi adalah kepala pemerintahan, namun kedaulatan ada di tangan Allah. ${ }^{12}$

Sebuah awal yang berbeda sekali dengan lazimnya awal sebuah system politik manapun. Pada umumnya, sebuah system politik selalu diawali penguasa dengan mencari massa dengan cara-cara propogandis dan intimidasi, kebimbangan dan kegelisahan rakyat

\footnotetext{
${ }^{8}$ Badri Yatim, Sejarah., Ibid, hlm. 27.

${ }^{9}$ John L. Esposito, Islam Kekuasaan Pemerintahan, Doktrin Iman dan Realitas Sosial, terj. M.Khoirul Anam, (Jakarta: Inisiasi Press, 2004), hlm. 15.

${ }^{10}$ Jamal Albana, Runtuhnya Negara Madinah (Islam Kemasyarakatan versus Islam Kenegaraan), terj. Jamadi Sunardi dan Abdul Mufid, edt. Khotimatul Husna, (Yogyakarta: Pilar Media, 2005), hlm. 9.

${ }^{11}$ Jamal Albana, Runtuhnya., Ibid., hlm. 7.

${ }^{12}$ M. Abdul Karim, Sejarah Pemikiran dan Peradaban Islam, (Yogyakarta: Bagaskara, 2012), hlm. 74.
} 


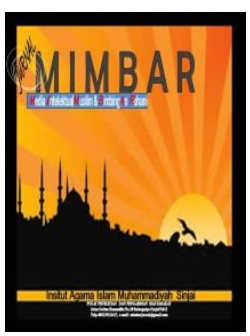

Jurnal Media Intelektual Muslim dan Bimbingan Rohani

Volume 5, No. 2, 2019

ISSN (print) : 2442-3217

ISSN (online) : 2716-3806

Homepage : http://journal.iaimsinjai.ac.id/indeks.php/mimbar

dan pengusaha berusaha menjelek-jelekkan lawan politiknya. Bahkan berusaha menghancurkannya dengan sikap hipokritnya. Hal seperti ini tidak ditemukan dalam negara Madinah. Dan sebagai gantinya justru rakyatlah yang dengan sukarela menyerahkan kekuasaan itu pada pemimpinya dan mereka mewajibkan dirinya sendiri untuk menaatinya. $^{13}$

Dengan terbentuknya negara Islam Madinah yang telah menjadi pusat pemerintahan sekaligus puncak keemasan Islam pada era kenabian yang sulit ditemui kesamaannya hingga kini sebab di dalamnya dipadukan teori politik kekuasaan dan toleransi keagamaan dibawa hegemoni kekuasaan Islam yang diperankan oleh Nabi Muhammad SAW.

\section{Islam dan Politik}

Islam dan politik adalah dua rangkaian kata yang memiliki pengertian yang berbeda, jika dikaitkan keduanya maka pengertian yang melekat dalam konteks kemoderenan adalah politik Islam. Jika merujuk pada kata dasarnya, Islam; adalah suatu agama yang dibawa oleh Nabi Muhammad SAW yang membawa kemaslahatan umat dan keselamatan dunia dan akhirat. Sedangkan politik berasal dari bahasa Latin politicus dan bahasa Yunani politicos, artinya (sesuatu yang) berhubungan dengan warga negara atau warga kota. Kedua kata itu berasal dari kata polis maknanya kota. Dalam KBBI berarti mengenai ketatanegaraan atau kenegaraan pemerintahan, dasar pemerintahan ${ }^{14}$, Tijani Abdul Qadir Hamid mengutip Maurice Douferg mendefinisikannya politik adalah seni memerintah dan mengatur masyarakat manusia. ${ }^{15}$ Dari pengertian di atas maka dalam konteks ini dapat dipahami bahwa Islam politik-politik Islam adalah suatu alat atau strategi yang digunakan untuk mencapai tujuan inti dalam suatu pemerintahan dalam kenegaraan yang berasaskan nilai-nilai transedental dan syariat Islam.

Jika kembali pada fakta sejarah peta politik yang telah digambarkan dan dipraktekkan Rasulullah SAW yang berlandaskan syariah Islam, sehingga pemerintahan

\footnotetext{
${ }^{13}$ Jamal Albana, Runtuhnya., hlm. 27.

${ }^{14}$ Suharso dan Ana Retnoningsih, Kamus Besar Bahasa Indonesia, Edisi Lux, (Semarang: Widia Karya, 2011), hlm. 386.

15 Tijani Abdul Qadir Hamid, Pemikiran., hlm. 3
} 


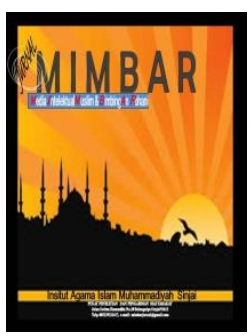

Jurnal Media Intelektual Muslim dan Bimbingan Rohani

Volume 5, No. 2, 2019

ISSN (print) : 2442-3217

ISSN (online) : 2716-3806

Homepage : http://journal.iaimsinjai.ac.id/indeks.php/mimbar

dalam negara Madinah mencapai keadilan dan kemakmuran maka dengan demikian inilah yang dinamakan praktek politik Islam. Muhammad Dhiauddin Rais mengemukakan bahwa Sistem yang dibangun oleh Rasulullah SAW dan kaum mukminim yang hidup bersama beliau di Madinah-jika dilihat dari segi praksis dan diukur dengan variablevariabel politik era modern-tidak disanksikan lagi dapat dikatakan bahwa system itu adalah system politik par excellence. Dalam waktu yang sama, juga tidak menghalangi untuk dikatakan bahwa system itu adalah system religius, jika dilihat dari tujuantujuannya, motif-motifnya dan fundamental maknawi tempat system itu berpijak. ${ }^{16}$

Islam sebagai agama yang sempurna tak hanya merangkum urusan kehidupan manusia semata melainkan kesempurnaanya memuat pula metode-strategi (baca:politik) yang diperlukan manusia untuk mempermudah orientasi kehidupannya, sebagaimana yang telah dicontohkan Nabi dan sahabatnya ketika masa hidup. Karenanya Islam dan politik merupakan suatu kesatuan yang tak terpisah dan solid, politik Islam yang telah menjadi fakta sejarah sebagai suatu strategi yang dipergunakan dalam pemerintahan Islam dan penyebaran Islam masa lalu. Kendati teori politik yang oleh pakar-pakar intelektual politik barat-orientalisme tidak banyak mengakui teori politik Islam, namun dapat dikatakan bahwa politik Islam banyak pula dijadikan rujukan dari abad pertengahan hingga sekarang baik kalangan muslim itu sendiri maupun intelektual politik barat. Intinya politik Islam sangat berpengaruh terhadap perpolitikan dunia.

Dalam politik Islam beberapa fakta sejarah yang tidak dapat diperselisihkan dalam bangunan masyarakat politik atau negara yang memulai kehidupan aktifnya, menjalankan tugas-tugasnya, dan mengubah prinsip-prinsip teoretis menuju dataran praktis telah tersempurnakannya kebebasan dan kedaulatan, yang pertama, setelah pembacaan Baiat Aqabah I dan II yang dilakukan oleh Rasulullah SAW dengan utusan dari Madinah, yang dilanjutkan dengan peristiwa hijrah, pada faktanya kedua baiat ini tidak diragukan oleh seorang pun tentang keberlansungannya-merupakan suatu titik transformasi dalam

\footnotetext{
${ }^{16}$ Muhammad Dhiauddin Rais, Teori Politik Islam, terj. Abdul Hayyie al-Kattani dkk, (Jakarta: Gema Insani Press, 2001), hlm. 4.
} 


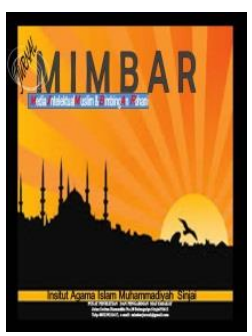

\section{MIMBAR}

Jurnal Media Intelektual Muslim dan Bimbingan Rohani

Volume 5, No. 2, 2019

ISSN (print) : 2442-3217

ISSN (online) : 2716-3806

Homepage : http://journal.iaimsinjai.ac.id/indeks.php/mimbar

Islam. ${ }^{17}$ Maka tindakan ini dapat dikatakan sebagai tindakan politik, karena negara Islam merupakan negara yang baru tumbuh. Kedua, hak berijtihad, ijtihad telah diakui sebagai salah satu sumber hukum Islam. Ketiga, pemberian wewenang kepada umat untuk menentukan segala hal yang berkaitan dengan detail-detail system pemerintahan Islam atau penentuan formatnya. ${ }^{18}$

\section{Terbentuknya Sistem Kekhalifahan}

Nabi wafat pada 12 Rabi' al-awal $10 \mathrm{H}$ bertepatan dengan 8 Juni $632 \mathrm{M}$ di Madinah, ${ }^{19}$ menjelang wafat, maka kaum muslimin akan segera merasa kehilangan dan kekosongan pemimpin dan melihat dihadapan mereka terbentang masalah-masalah dan tangggung jawab yang besar akibat dari kekosongan itu. Mereka mendapati bahwa mereka mendapatkan warisan negara atau system politik. Setiap individu diberi hak berpikir dan mengkaji masalah-masalah yang berhubungan dengan institusi negara itu. Mereka tidak dikekang oleh ikatan-ikatan tertentu untuk menggunakan hak mereka itu dan mencapai tujuannya, maka sejak mereka mulai mengolah pikiran tentang masalah itu, mulailah bermunculan beragam pendapat dan kecenderungan dalam melihat masalah. Fenomena ini tampak pertama kali dalam sejarah Islam dalam pertemuan Saqifah. ${ }^{20}$

Dengan diadakannya pertemuan di Balai Saqifat (Nadi al-Qaum) tersebut yang dihadiri oleh para tokoh Islam, baik dari kalangan Anshar dan Muhajirin, ada beberapa tokoh besar Islam yang tidak sempat hadir seperti Ali bin Abi Thalib. Pertemuan di Saqifah tersebut adalah salah satu pertemuan sejarah terpenting dalam seluruh sejarah Islam, beberapa pakar sejarah menyebutnya pertemuan tersebut seperti pertemuan nasional

${ }^{17}$ Ibid, hlm. 7.

${ }^{18}$ Islam telah menjamin keberadaan factor ini, saat ia mengakui keberadaan prinsip, yaitu prinsip kebebasan berpikir bagi individu, atau dengan ungkapan lain, terdapat pengakuan Islam akan hak individu untuk berpikir independen dan hak individu untuk mengikuti hasil yang dicapai oleh pemikirannya itu, dan hanya mengikuti kata hati. Inilah prinsip yang diakui dalam kitab-kitab fiqih dan ushul fiqih dengan nama Ijtihad. Ibid, hlm. 8-9.

${ }^{19}$ Ia memang membentuk suatu ummah (konfedarasi), akan tetapi untuk menjalankannya Nabi tidak tinggalkan wasiat, pesan atau menunjuk siapa diantara sahabatnya bakal menjadi khalifah. Pemikiran (persoalan politik) yang pertama muncul dalam Islam setelah wafatnya Nabi bukan masalah teologi. M. Abdul Karim. Sejarah., hlm.79.

${ }^{20}$ Muhammad Dhiauddin Rais, Teori., hlm. 10. 


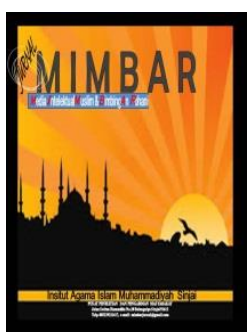

Jurnal Media Intelektual Muslim dan Bimbingan Rohani

Volume 5, No. 2, 2019

ISSN (print) : 2442-3217

ISSN (online) : 2716-3806

Homepage : http://journal.iaimsinjai.ac.id/indeks.php/mimbar

atau mukhtamar luar biasa pada masa kini. Kendati pertemuan tersebut berlangsung dalam

suasana duka ummat Islam dengan wafatnya Nabi, namun hal tersebut teramat penting untuk membahas nasib dan kelansungan kepemimpinan (imamah) Islam selanjutnya. ${ }^{21}$ Pemerintah (khalifah/imamah) ini berfungsi sebagai pengganti kedudukan nabi dalam tugas memelihara agama dan mengatur dunia. ${ }^{22}$

Beberapa teori pemikiran terpenting yang dilontarkan dalam pertemuan Saqifah tersebut adalah: pertama, teori membela kaum Anshar yang mengklaim diri mereka sebagai pihak yang berhak untuk memegang jabatan kekhalifahan, dengan alasan mereka membela Islam, menjaga dengan jiwa dan harta mereka dan memberikan tempat dan pertolongan, dan merekalah penduduk asli Madinah. ${ }^{23}$ Kedua, teori kedua merupakan bantahan atas teori pertama tadi, berupa pembelaan atas hak kaum Muhajirin atas jabatan kekhalifahan, dan membuktikan bahwa mereka lebih berhak atas jabatan kekhalifahan dibandingkan dengan yang lain. ${ }^{24}$

Dengan membuktikannya kaum Muhajirin sebagai pemegang jabatan kekhalifahan, dengan di-baiat ${ }^{25}$-nya Abu Bakar As-Shiddiq oleh kaum muslimin secara bersama-sama sebagai khalifah pertama, maka kepemimpinan politik, pemerintahan dan kekuasaan mutlak secara sah berada di tangah Abu Bakar As-Shiddiq. Alasan terpilihnya Abu Bakar As-Shiddiq dikarenakan beberapa pandangan para sahabat bahwa dia adalah lebih baik

${ }^{21}$ Walaupun pertemuan ini pada awalnya hanyalah golongan-golongan Anshar yang akan segera memutuskan kepemimpinan Islam selanjutnya, namun dengan kehadiran Abu Bakar As-Shiddiq dan sahabat-sahabat lainnya dari golongan Muhajirin maka perbincangan politik yang tengah berlansung diambil alih oleh Abu Bakar As-Shiddiq untuk memberikan keterangan-keterangan terkait pemutusan seorang pemimpin yang memiliki kriteria kepemimpinan.

${ }^{22}$ Lihat, Azyumardi Azra, dkk, Artikulasi Islam Kultural (Dari Tahapan Moral ke Periode Sejarah), Edt. Asep Gunawan, (Jakarta: PT. Raja Grafindo Persada, 2004), 57.

${ }^{23}$ Muhammad Dhiauddin Rais, Teori., hlm. 15. Dalam pandangannya ini mengemukakan bahwa teori membela kaum Anshar adalah teori pertama yang timbul dalam sejarah pemikiran dan politik Islam, namun jika dianalisis dengan kembali pada era kenabian terutama pada pembentukan Negara Islam Madinah dan pemerintahannya selama kurang lebih sepuluh tahun, disana telah terlihat teori-teori politik Islam yang telah dipraktekkan Nabi semasa pemerintahannya, baik dalam penyebaran Islam maupun dalam peperangan.

${ }^{24}$ Muhammad Dhiauddin Rais, Teori., Ibid,

${ }^{25}$ Dalam pengertian ini bai'at berarti persetujuan terhadap pencalonan seorang bakal pemegang khalifah dan kesepakatan atas pencalonannya. Dalam hal ini pencalonan (bai'at) terhadap Abu Bakar AshShiddiq adalah peristiwa bai'at politik pertama sepanjang sejarah Islam. Lihat, Rusjdi Ali Muhamamad, Politik Islam, Sebuah Pengantar, (Yogyakarta: Pustaka Pelajar kerja sama BDI PT.Arun BDI PIM dan Yasat, 2000), 45. 


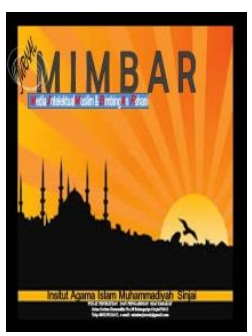

Jurnal Media Intelektual Muslim dan Bimbingan Rohani

Volume 5, No. 2, 2019

ISSN (print) : 2442-3217

ISSN (online) : 2716-3806

Homepage : http://journal.iaimsinjai.ac.id/indeks.php/mimbar

dan lebih berhak melanjutkan pemerintahan, dia memiliki peranan sebagai asisten pribadi Nabi ketika masih hidup, dan setia mendampinginya dalam hal apapun. Namun dipihak lain desas-desus dan kemungkinan akan klaim jabatan kekhalifahan dari Ali bin Abi Thalib-golongan Syi'ah (golongan yang membela Ali Bin Abi Thalib) merasa bahwa hanya Ali yang lebih berhak menduduki jabatan kekhalifahan tersebut.

Ketika Abu Bakar As-Shiddiq terpilih sebagai pengganti pertama Nabi, dengan jelas mendefinisikan batas-batas peranan dan kekuasaannya sebagai kepala negara Islam menyatakan, sebagaimana Mumtaz Ahmad mengutip Abul A’la Maududi, bahwa:

"Saya telah diangkat sebagai penguasa kalian, meskipun saya bukanlah yang terbaik diantara kalian. Bantulah saya bila saya benar, koreksi saya bila berbuat kesalahan. Orang yang lemah diantara kalian akan menjadi kuat dihadapan saya sehingga saya memberikan haknya, apabila Allah menghendaki, dan orang yang kuat diantara kalian akan menjadi lemah di hadapan saya sehingga saya membuatnya melakukan kewajiban, apabila Allah menghendaki. Patuhlah kepadaku selama aku taat kepada Allah dan Rasul-Nya; apabila aku tidak taat kepada mereka, maka kamu tidak perlu patuh kepadaku”, ${ }^{26}$

Dsinilah terlihatkan salah satu potret perpolitikan yang telah dipraktekkan sahabat Nabi (Abu Bakar As-Shiddiq) dengan teori politi Islam dengan asas-asas ketauhidan. Mengedepankan prinsip yang berkesadaran dan kesederhanaan dalam misi politik kekuasaan yang akan dijalankan sebagai pelanjut risalah Nabi, membawa misi penyebaran Islam. System, teori politik dan demokrasi tidak hanya dipotretkan dalam pembentukan system pembentukan kekhalifahan sebagaimana awalnya Abu Bakar menjadi khalifah pertama, namun pada kelangsungan kekhalifahan setelahnya banyak mengalami polemik dan dinamika system politik Islam.

\section{E. Lahirnya Sekte-Sekte dan Sebab Kemunculan Teori-Teori Islam}

Dalam catatan sejarah perkembangan Islam terutama pemerintahan dari generasi ke generasi yaitu dari zaman Rasulullah SAW hingga kekhalifahan-terutama tahun-tahun terakhir kekhalifahan Utsman, dari awal kemajuan dan perkembangan dalam konsekwensi

\footnotetext{
${ }^{26}$ Mumtaz Ahmad, Masalah., hlm. 19.
} 


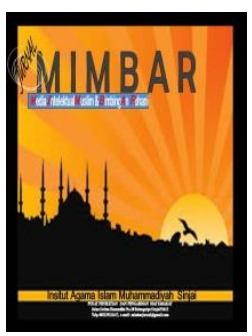

Jurnal Media Intelektual Muslim dan Bimbingan Rohani

Volume 5, No. 2, 2019

ISSN (print) : 2442-3217

ISSN (online) : 2716-3806

Homepage : http://journal.iaimsinjai.ac.id/indeks.php/mimbar

kehidupan masyarakat nampak dikekhalifahan ini menurun langkahnya. Jika ditinjau dari sudut perpolitikannya walaupun memiliki keistimewaan dan kebijakan serta sebagai pemimpin yang tegas, namun situasi masyarakat Islam yang telah berbeda ketika masa Nabi dan khalifah sebelumnya telah membawa perubahan kepemimpinan dan perpolitikan, efek-efek yang ditimbulkan menjadi luar biasa sehingga dapat dikenal sebagai masa kritis dan transisi pada perjalanan sejarah ini. Ketidakstabilan politik dan permasalahan dalam dunia Islam yang tak dapat dihindarkan menjadikannya khalifah Utsman terseret dalam situasi pemerintahan yang serba kritis hingga persoalan-persoalan itu pun berakhir dengan tragis yaitu dengan kematian.

Kegoncangan yang dialami oleh kaum muslimin dengan situasi politik pasca kematian khalifah Utsman atas tragedi pembunuhan yang dilakukan oleh Saudan membawa perubahan yang sangat mencekam dikalangan umat Islam. Sepeninggal Utsman tiada pilihan lain untuk dijadikan khalifah penerus Utsman kecuali Ali bin Abi Thalib. Ali dibaiat oleh dewan formatur bentukan Umar yang masih ada secara aklamasi kemudian diikuti secara umum oleh umat Islam di Masjid Nabawi. ${ }^{27}$ Fuad Muhammad Fachruddin menjelaskan, baiat pada saat itu tidak meletakkan batas tindak yang layak bagi pemberontakan hingga timbul api yang dapat memakan fitnah. Pada dasarnya keadaan ini telah menimbulkan kelompok yang masing-masing mempunyai benteng pertahanan yang besar yaitu, (1) Kelompok penyokong Ali ra dan, (2) Kelompok yang berpihak kepada Mua'wiyah. $^{28}$

Timbulnya kelompok-kelompok tersebut tidak lain adanya kepentingan politik yang semata politik seseorang untuk menjadi kepala negara. Perjalanan kekhalifahaan Ali bin Abi Thalib yang diwarnai pula dengan pergulatan dan goncangan politik hingga membawa sejarah terulang dengan kematian yang dialami pula oleh Ali bin Abi Thalib pasca perang Shiffin. Dari sejarah kekhalifahaan tersebut membawa pada kondisi dan situasi yang berbeda-beda, namun yang paling mencolok adalah timbulnya gerakan-gerakan reformis

\footnotetext{
${ }^{27}$ Lihat, Hamiyatul Alyah, Sketsa Historis Politik Islam Masa al-Khulafa al-Rasyidun, dalam Sejarah Politik Islam (Panggung Pergulatan Politik Kekuasaan dari Timur Tengan Hingga Asia, (Yogyakarta: Nusantara Press, 2011), hlm. 78.

${ }^{28}$ Fuad Mohd. Fachruddin, Pemikiran Politik Islam, (Jakarta: Pedoman Ilmu Jaya, 1998), hlm. 86.
} 


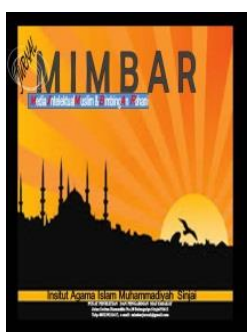

Jurnal Media Intelektual Muslim dan Bimbingan Rohani

Volume 5, No. 2, 2019

ISSN (print) : 2442-3217

ISSN (online) : 2716-3806

Homepage : http://journal.iaimsinjai.ac.id/indeks.php/mimbar

yang akan membawa pada revolusi yang disebabkan faktor ekonomi, politik dan pemikiran. Disinilah terjadi perubahan mendasar yang membentuk masyarakat dan kian berubah. Perubahan generasi lama yang berpola pemerintahan dan politik seperti yang dicontohkan Rasul, drastis tergantikan dengan pola generasi baru.

Kurangnya kualitas yang dimiliki oleh generasi belakang jika dibandingkan dengan generasi sebelumnya-masa Rasul, khalifah pertama dan kedua baik dari segi hukum pemerintahan dan substansi aqidah masyarakat, ditambah dengan negara yang dipimpin oleh khalifah belakangan kian luas dengan adanya hasil ekspansi besar-besaran telah memunculkan fanatisme dan ketamakan hingga sulitnya ditemukan pemimpin yang unggul dan menginspirasi. Dalam pandangan Muhammad Dhiauddin Rais, kepemimpinan yang unggul, mengarahkan dan menginspirasi yaitu pemimpin yang memiliki sifat-sifat dan karakteristik yang unggul, yang tidak sembarang dimiliki oleh semua orang, seperti kebijaksanaan, kecakapan, keluasan cakrawala, keluasan pandangan dan niat suci. ${ }^{29}$

Sepanjang situasi politik pada kekhalifahan belakangan telah melahirkan firqahfirqah (sekte-sekte) baru atau munculnya mazhab teologi Islam membawa keretakan persatuan umat Islam yang bertentangan dengan era terdahulu, muncul konflik-konflik dan perselisihan hingga membawa dendam yang berkepanjangan. Lebih lanjut Dhiauddin Rais bahwa proses pencarian, saling curiga, dan tidak ada rasa aman yang stabil inilah membuat kelompok-kelompok membentuk opini masing-masing, berpikir dan merumuskan teoriteori. Bahkan setiap kelompok memobilisasi kekuatan diri dan membentuk kubu-kubu dalam rangka mewujudkan teori-teori tersebut dan mengaplikasikannya secara nyata. ${ }^{30}$

Dari tinjauan munculnya sekte-sekte tersebut, maka dapat disimpulkan alasan dan yang mempengaruhinya yaitu, Pertama, ketidakpuasan sebagian (kelompok) umat Islam dengan cara-cara politik dan pemerintahan yang dilakukan oleh khalifah belakangan dan gubernurnya. Kedua, ragamnya bentuk propaganda yang dilancarkan oleh kelompok tertentu untuk mendapatkan dukungan politik praktis. Ketiga, keinginan yang besar untuk menunjukkan kepada ummat Islam atas klaim kebenarannya. Keempat, keinginan

\footnotetext{
${ }^{29}$ Muhammad Dhiauddin Rais, Teori., hlm. 22.

${ }^{30}$ Ibid, hlm. 25.
} 


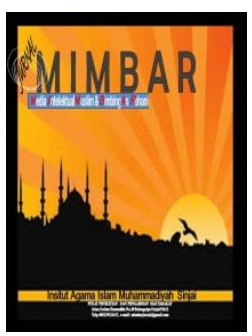

Jurnal Media Intelektual Muslim dan Bimbingan Rohani

Volume 5, No. 2, 2019

ISSN (print) : 2442-3217

ISSN (online) : 2716-3806

Homepage : http://journal.iaimsinjai.ac.id/indeks.php/mimbar

mewujudkan teori politik dan prinsip-prinsipnya untuk dijadikan pedoman pemerintahan dan sekaligus syariat. Kelima, sikap fanatisme dan kekuasaan oleh pemuka-pemuka Islam dan cenderung berwatak revolusi kepada pemimpin yang sah.

\section{F. Teori-Teori yang Muncul}

Seperti yang telah dikemukakan sebelumnya terkait alasan munculnya sekte-sekte (timbulnya perpecahan) yakni mewujudkan teori politik sekali gus sebagai pedoman pemerintahan, maka ada beberapa teori yang muncul pada era kekhalifahan semasa Utsman, Ali maupun Mua'wiyah ini dapat dijadikan sebagai sebuah perkembangan pemikiran.

Beberapa teori tersebut adalah:

Pertama, Pemecatan Wali (Gubernur). Beberapa kelompok Islam semasa kekhalifahan Utsman bin Affan meresolusikan teori bahwa wali atau gubernur sebuah wilayah yang berfungsi sebagai wakil khalifah wajib dipecat apabila orang-orang yang diperintah (rakyat) tidak merestui system politik dan tingkah lakunya. ${ }^{31}$ Teori politik ini pun berkembang hingga kepemerintah pusat (posisi khalifah Utsman), Alasan kecenderungan politik ini dikarenakan khalifah Utsman melakukan beberapa pelanggaran dalam pemerintahannya baik memberikan jabatan-jabatan penting khusus anggota keluarganya yang berasal dari Bani Umaiyah, hingga berujung pada sebuah revolusi.

Kedua, Klaim Quraisy. Pemikiran dan opini politik yang muncul pada periode ini adalah adanya penolakan terhadap klaim atau pernyataan Quraisy dalam hal keistimewaannya atas seluruh bangsa Arab dan hak mereka menduduki kekhalifahan dan pemerintahan serta menguasai sektor-sektor luas.

Ketiga, Pendapat Abdullah bin Saba'. Teori ini pada gilirannya akan memiliki gaung yang cukup besar dikemudian hari, yang mulai dirumuskan oleh Abdullah bin Saba', diantara pendapatnya yaitu "Setiap nabi mempunyai pewaris dan Ali adalah pewaris Muhammad: maka siapa yang zalim dari orang-orang yang tidak membolehkan wasiat

31 Seperti penduduk Kuffah menuntut pemecatan wali yang waktu itu dijabat oleh al-Walid bin Uqbah al-Umawi, saudara seibu Utsman dengan beberapa alasan diantaranya mereka menuduhnya bahwa dia sering mengobrol dengan Abi Zubaid ath-Tha'I, seorang pemuda penyair Nasrani dan mereka samasama mabuk, sebagian dari mereka menjadi saksi. Lihat, Ibid, hlm. 26-30 


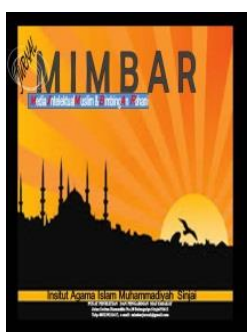

MIMBAR

Jurnal Media Intelektual Muslim dan Bimbingan Rohani

Volume 5, No. 2, 2019

ISSN (print) : 2442-3217

ISSN (online) : 2716-3806

Homepage : http://journal.iaimsinjai.ac.id/indeks.php/mimbar

atau peninggalan Rasulullah?, disinilah awal mulanya teori wishayah (wasiat atau pemberian mandat), kemudian pendapatnya, "Utsman telah mengambil wasiat tersebut tanpa hak, maka bangkitlah kalian dari urusan ini dan mulailah mendiskreditkan para pemimpin wilayahmu, perlihatkanlah amar ma'ruf nahi mungkar. Hal ini diperkuat oleh Fuad Mohd. Fachruddin ${ }^{32}$ yang mengemukakan bahwa pendapat ini sangat mempengaruhi tekad kepercayaan “Golongan Syi’ah” dikemudian hari.

Keempat, Teori Abu Dzar dalam Masalah Harta. ${ }^{33}$ Abu Dzar telah menyerukan suatu teori yang memiliki signifikansi secara sosial dan politik, yang didasarkan atas ijtihad dan pemahamannya terhadap ruh agama Islam, dan untuk mengantisipasi kondisi faktual yang kini dialami oleh masyarakat Islam pascafutuhat (penaklukan). Dia telah membantah perkataan Mua'wiyah gubernur Syam yang mengatakan, "Semua harta dan milik Allah", Abu Dzar mengatakan "seakan-akan dia ingin menguasai harta tersebut tanpa melibatkan kaum muslimin-seorang muslimin tidak pantas baginya memiliki lebih dari kebutuhan pokoknya sehari semalam atau sesuatu yang disumbangkan dijalan Allah, atau dia persiapkan untuk orang yang terhormat.

\section{G. Munculnya Partai-Partai}

Kemunculan partai-partai berawal dari era kekhalifahan Ali bin Abi Thalib. Pembaiatan Ali ketika di Madinah yang didukung oleh kaum Muslimin untuk menggantikan khalifah Utsman menorehkan cacatan sejarah Islam yang sangat besar, meskipun pembaiatan Ali sebagai pemimpin untuk melanjutkan tugas kenegaraan dan memberantas bentuk-bentuk ketidakadilan namun tetap saja ada beberapa kelompok Islam yang tidak menyetujuinya. Kekhalifahan ini memunculkan polemik dua kelompok besar yang berbeda karakter misi. Yang pertama adalah kelompok pendukung Ali dan kedua adalah kelompok Mua'wiyah.

\footnotetext{
${ }^{32}$ Fuad Mohd. Fachruddin, Pemikiran., hlm. 81.

${ }^{33}$ Muhammad Dhiauddin Rais, Teori., hlm. 30
} 


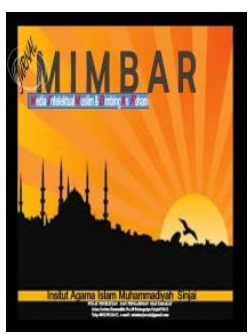

Jurnal Media Intelektual Muslim dan Bimbingan Rohani

Volume 5, No. 2, 2019

ISSN (print) : 2442-3217

ISSN (online) : 2716-3806

Homepage : http://journal.iaimsinjai.ac.id/indeks.php/mimbar

Dalam catatan sejarah munculnya partai-partai ini berawal dari peristiwa Tahkim ${ }^{34}$ yang menguntungkan pihak Mua'wiyah dengan kelicikan Amr bin Al-Ash atas Abu Musa al-Asy’ari sebagai wakil dari kelompok Ali. Akhir perang Shiffin dan terjadinya peristiwa tahkim melahirkan dua kubu yakni kubu Syi'ah yang bertahan sebagai pengikut Ali, dan kubu yang keluar dari pengikuti Ali sebagai kubu Khawarij. Khairuddin Yujah Sawiy ${ }^{35}$ mengemukakan bahwa ketika suku-suku pendukung Ali terpecah menjadi dua kelompok saat menggapai tawaran perdamaian kelompok Mua'wiyah pada perang Shiffin, maka akan jelas diketahui kalau kedua kelompok tersebut berada dalam posisi yang sangat dilematis. Pada akhirnya kejadian ini memunculkan semangat primordialisme yang tinggi dan menjadi boomerang bagi pemerintahan Ali.

Akhir dan kegagalan dari peristiwa tahkim yang berbuah dengan pembaiatan Mua'wiyah sebagai khalifah, maka partai politik pertama terbentuk dalam sejarah Islam, dan tokoh-tokohnya tampil diatas panggung peristiwa-peristiwa, memiliki system aturan dan diantara ciri khas kehidupannya adalah kehendak untuk mempertahankan kontinuitas pemerintahan. Dalam riwayat lain tentang keputusan kedua utusan dalam tahkim (arbitrase) seperti yang dikemukakan oleh Abu al-Hasan al-Mas'udi dalam Dhiauddin Rais bahwa kedua-duanya sepakat untuk mencopot Ali dan Mua'wiyah, dan setelah itu dilimpahkan persoalannya kepada syura' yang didalamnya umat akan memilih yang pantas baginya. Jadi ini adalah pendapat mereka, dan ini adalah hasil akhir dari at-Tahkim: keduanya telah melimpahkan persoalan kepada umat. ${ }^{36}$ Tidak lama kemudian pasca Tahkim yang menguntungkan pihak Mua'wiyah dan masa pemerintahan selanjutnya, seperti yang diungkap oleh para sejarawan Islam bahwa sistem kekhalifahan berubah menjadi system kerajaan "monarki absolute" hingga pada pemerintahan putra

\footnotetext{
${ }^{34}$ Peristiwa ini terjadi ketika perang Shiffin (26 Juli $657 \mathrm{M}$ ), yang mempertemukan kekuatan Mua'wiyah dan Ali, terjadi adu tekhnik kelicikan. Atas usulah Amr ibn al-Ash, Mua'wiyah menawarkan perdamaian dengan mengangkat al-Qur'an, akhirnya perang berhenti. Dua tahun kemudian di Dumatul Jandal bertemu antara pihak Ali dan Mua'wiyah yang masing-masing berjumlah 400 orang yang akhirnya tahkim gagal total akibat tipu muslihat dari Amr bin al-Ash. Lihat, M. Abdul Karim. Sejarah., hlm.107.

${ }^{35}$ Khairuddin Yujah Sawiy, Perebutan Kekuasaan Khalifah, (Menyingkap Dinamika dan sejarah Politik Kaum Sunni), (Yogyakarta: Safiria Insania Press, 2005), hlm. 7-8.

${ }^{36}$ Muhammad Dhiauddin Rais, Teori., hlm. 34 \& 35.
} 


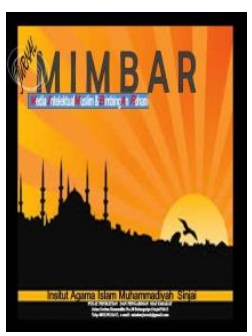

\section{MIMBAR}

Jurnal Media Intelektual Muslim dan Bimbingan Rohani

Volume 5, No. 2, 2019

ISSN (print) : 2442-3217

ISSN (online) : 2716-3806

Homepage : http://journal.iaimsinjai.ac.id/indeks.php/mimbar

mahkotanya Yazid sehingga dengan inilah dapat dianggap bahwa Mua'wiyah adalah peletak dasar system kerajaan dalam Islam.

\section{H. Khawarij dan Pemikirannya}

Peristiwa perang Shiffin ketika kekhalifahan Ali bin Abi Thalib yang telah melahirkan kelompok Khawarij sebagai kelompok yang keluar dari pasukan Ali setelah memprotes terhadap tahkim. Kelompok ini keluar dari barisan pasukan Ali sehingga diberi gelar Khawarij (orang-orang yang keluar). Dalam pandangan Khawarij, mereka keluar dari pendukung Ali yang semula sama-sama menentang Mua'wiyah yang memberontak terhadap kekhalifahan Ali.

Dengan terjadi peristiwa tahkim beberapa alasan sehingga membentuk kelompok tersendiri (Khawarij) ini dengan menentang khalifah Ali bin Thalib dan Mua'wiyah sekaligus bentuk ketidakpuasannya diantaranya yaitu; Pertama, keputusan peristiwa tahkim yang diambil oleh kedua belah pihak (Ali dan Mua'wiyah) tidak berdasar pada hukum Allah SWT. Kedua, Ali bin Abi Thalib dan Mua'wiyah sejak pemerintahannya telah menyalahgunakan harta rakyat. Ketiga, kepemimpinan Mua'wiyah tidak mengakui Ali sebagai khalifah. Keempat, Ali dan Mua'wiyah dalam kepemimpinannya telah meniru pola hidup kaisar Romawi yang terlalu hedonis. Kelima, Pacsa peristiwa tahkim, mereka menilai Ali dan Mua’wiyah kedua-duanya telah kafir.

Walaupun pada awalnya kelompok ini dapat didamaikan oleh khalifah Ali, namun berselang waktu terutama pasca peristiwa perang Shiffin kelompok ini pun makin tumbuh dan melakukan teror dan pemberontakan walaupun pada akhirnya dapat dimusnahkan. Namun khalifah Ali pun terbunuh oleh seorang komplotan Khawarij yang bernama Abdurrahman bin Muljan.

Dasar gerakan meraka adalah laa hukma illaa lillaah, sebuah ungkapan yang artinya “tidak ada hukum kecuali hukum Allah". Slogan ini dijawab oleh Ali dengan ungkapan, kalimat al-haqqi, urida biha al-bathil yang artinya kalimat haq yang diucapkan untuk tujuan kebatilan. Slogan ini akhirnya ditafsirkan bahwa setiap keputusan politik, harus berdasar Al-Qur'an. Bagi golongan Khawarij, siapa pun umat Islam yang diluar 


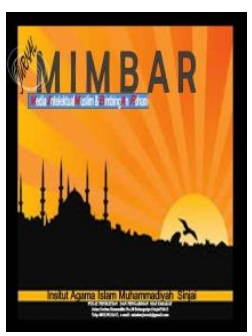

Jurnal Media Intelektual Muslim dan Bimbingan Rohani

Volume 5, No. 2, 2019

ISSN (print) : 2442-3217

ISSN (online) : 2716-3806

Homepage : http://journal.iaimsinjai.ac.id/indeks.php/mimbar

golongannya adalah kafir. Pemikiran politik mereka antara lain; ${ }^{37}$ Pertama, pemilihan khalifah tidak berlaku kecuali dengan pemilihan bebas dan benar oleh seluruh umat Islam, bukan oleh satu golongan saja. Kedua, seorang khalifah tidak dibatasi waktu pemerintahannya selama masih menegakkan keadilan. Ketiga, jika tidak adil maka wajib dipecat atau dibunuh. Keempat, jabatan khalifah terbuka untuk tiap laki-laki muslim, merdeka, Arab tanpa pandang suku. Kelima, pengangkatan imam bukan merupakan kewajiban agama. Keenam, mengakui pemerintahan Abu Bakar dan Umar, enam tahun pertama pemerintahan Utsman dan pemerintahan Ali sebelum tahkim.

\section{Teori Syi’ah}

Muchotob Hamzah mengutip Zahrah mengemukakan pokok-pokok pikiran politik Syi'ah yaitu ${ }^{38}$, Pertama, imam seharusnya dari keturunan Fatimah, tapi menurut Syi'ah Zaidiyah boleh juga dari kelompok yang lain asal memenuhi syarat. Kedua, Abu Bakar dan Umar sah menjadi khalifah meskipun Ali lebih utama (Syi'ah Zaidiyah), sementara Syi'ah Imamiyah menganggap Abu Bakar dan Umar tidak sah. Ketiga, Imam tidak maksum (terbebas dari dosa) Syi'ah Zaidiyah, sementara Syi'ah Imamiyah menganggapnya sebagai maksum. Keempat, tidak ada imam yang tersebut (syi'ah Zaidiyah), sementara Syi'ah Imamiyah Itsna 'Asyriah menganggap imam kedua belas telah menghilang dan akan muncul diakhir zaman, Kelima, kedudukan Ali menurut Imamiyah itsna 'Asyriah setingkat lebih tinggi dari pada umumnya manusia, Keenam, menurut Syi'ah Zaidiyah, diperbolehkan membaiat dua imam pada dua daerah, asal memenuhi syarat dan disepakati, dengan pilihan bebas oleh majelis atau ditempat ia merebut kekuasan.

Kaum Syi'ah akhirnya menetapkan bahwa penguasa adalah kekuatan illegal yang merampas kekuasaan dari ahlul bait, mereka menguasai ummat dengan kaidah mereka. Penguasa-penguasa itu mengharamkan kaum muslimin dan ummat manusia untuk menggunakan hukum ilahi, karena kecintaan mereka terhadap jabatan dan kekuasaan serta

\footnotetext{
${ }^{37}$ Muchotob Hamzah, Menjadi Politisi Islami (Fikih Politik), (Yogyakarta: Gama Media, 2004),
} hlm. 34

38 Ibid, hlm.32-33. 


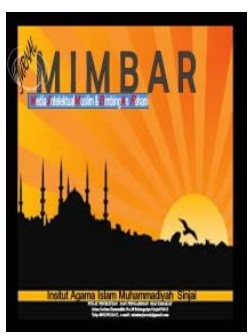

\section{MIMBAR}

Jurnal Media Intelektual Muslim dan Bimbingan Rohani

Volume 5, No. 2, 2019

ISSN (print) : 2442-3217

ISSN (online) : 2716-3806

Homepage : http://journal.iaimsinjai.ac.id/indeks.php/mimbar

ketamakan mereka terhadap dunia atas kecintaannya terhadap akhirat. ${ }^{39}$ Tujuan utama orang-orang Syi'ah adalah bersatunya ummat Islam dibawah pimpinan Imam ahlul bait, yang akan memimpin dalam memberikan penjelasan tentang hukum-hukum aqidah ilahi dan penerapannya dalam kehidupan nyata. ${ }^{40}$

\section{J. Lahirnya Mu’tazilah dan Pokok Pikiran Politik}

Sebenarnya Mu'zilah sebagai gerakan dan sikap politik, lahir di Madinah oleh Abdullah bin Umar bin Khattab yang tidak ikut campur dalam perselisihan politik di antara sahabat. Ia memusatkan perhatiannya pada sunnah Nabi SAW. Yang kelak akhirnya disebut sebagai ahlu al-sunnah wa al-jama'ah. Adapun Mu'tazilah yang sampai kini masih hidup, adalah sebutan untuk kelompok yang punya paham aqidah dan sikap politik yang dipelopori oleh Washil bin 'Atha' yang memisahkan diri (i'tazala) dari gurunya, Hasan Basri. Berbeda dengan i'tizalnya Abdullah bin Umar bin Khattab yang kurang menyetujui pembaiatan Ali Bin Abi Thalib, kaum Mu'tazilahnya Washil bin 'Atha' ini lebih condong kepada kekhalifahan keturunan Ali Bin Abi Thalib, r.a. Pokok-pokok pikiran politik Mu'tazilah, antara lain; ${ }^{41}$ Pertama, mengakui kekhalifahan Abu Bakar dan Umar bin Khattab. Kedua, tidak tegas sikapnya terhadap pemerintah khalifah Utsman dan pemberontak yang membunuhnya. Ketiga, menganggap Ali lebih berhak menduduki jabatan khalifah dari pada Usman. Keempat, soal imamah adalah merupakan pilihan rakyat. Kelima, khalifah tidak harus dari suku Quraisy. Keenam, khalifah tidak harus mukmin muslim, adil tanpa pandang suku. Mengangkat imam bukan merupaka kewajiban agama, manakala keadilan sudah merata.

\section{K. Ahlul Hadis dan Sunnah}

Fuad Mohd. Fachruddin mengemukakan bahwa golongan "Ahli Sunnah wal Jamaah” ini salah satu golongan yang mengikuti jejak Qur'an dan Sunnah. Dan tempat kedudukan mereka adalah Madinah el-Munawwarah. Yang dimaksud dengan "Sunnah" ialah ucapan, perbuatan, dan penerimaan Rasulullah SAW atas perbuatan yang dibenarkan

\footnotetext{
${ }^{39}$ Maryadi, eds, Telaah Kritis tentang Keadilan Para Sahabat dan Referensi Politik dalam Islam, (Surakarta, Muhammadiyah University Press, 2002), hlm. 531.

${ }^{40}$ Maryadi, eds, Telaah., Ibid, hlm. 530.

${ }^{41}$ Muchotob Hamzah, Menjadi., hlm. 30-31.
} 


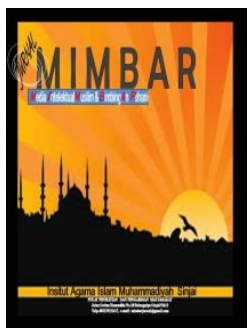

beliau. Maka dengan demikian yang dikatakan "ahlul hadits" adalah mereka yang berpegang kepada ucapan Rasulullah SAW. ${ }^{42}$

Ahlul Sunnah, mereka memilih jalan damai dengan penguasa dan ikut kepada mereka, karena ditangan mereka akan tercapai persatuan ummat. Tahun dimana Mu'awiyah dapat mengalahkan Ali dinamakan dengan 'Aam Jama'ah (tahun persatuan) dan orang-orang yang mengikuti Mua'wiyah disebut dengan Ahlus-Sunnah. Kelompok ini terbagi dalam beberapa kelompok yang berbeda-beda kesetiaanya kepada penguasa. Perbedaan itu disebabkan rasa sayang mereka terhadap ahlul bait dan keinginan untuk melakukan perlawanan. Akan tetapi mayoritas mereka berkeyakinan bahwa semua orang yang menjadi penguasa ketika itu adalah sahabat nabi. Mengenai kepemimpinan daulah, kelompok ini berpendapat bahwa mereka akan mengikuti kelompok yang menang, meski bagaimanapun caranya memperoleh kemenangan itu. Hujjah yang mereka pergunakan sebagai dalih adalah perkataan Abdullah bin Umar pada hari "Hirrah", "Kami bersama kelompok yang unggul", perkataan ini akhirnya menjadi satu kaidah syariat. ${ }^{43}$ Adapun pokok-pokok pikiran politiknya antara lain; ${ }^{44}$ Pertama, mengakui keempat khulafa AlRasyidin. Kedua, mengangkat imam dan khalifah merupakan kewajiban agama. Ketiga, imam hendaknya dari suku Quraisy tetapi syarat ini kemudian diperlonggar. Keempat, terjadinya imam dapat melalui mubaya'ah, istiklaf taghallub yang kemudian diikuti dengan baiat. Kelima, imam dipilih oleh rakyat dengan jalan musyawarah, syarat-syarat anggota majelis antara lain syura antara lain, menguasai kitab Allah dan sunnah Rasulullah, mengamalkan kitab Allah SWT, Adil dan jujur, baligh dan dewasa.

\section{Firqah Murjiah}

Kelahiran Firqah Murjiah tidak begitu jelas, tetapi dapat dibatasi waktu munculnya, yaitu pada dekade-dekade terakhir dari abad pertama. Firqah ini lahir sebagai efek antithesis atau reaksi terhadap kehiperbolisan Khawarij dalam aqidah mereka dari segi pengafiran dan kekerasan bahwa amal adalah bagian yang tak terpisahkan dari iman. Menurut Khawarij, pelaku dosa besar bukanlah seorang mukmin. Orang-orang Murjiah

\footnotetext{
${ }^{42}$ Fuad Mohd. Fachruddin, Pemikiran., hlm. 127.

${ }^{43}$ Maryadi, eds, Telaah., hlm. 349-350.

${ }^{44}$ Muchotob Hamzah, Menjadi., hlm. 30.
} 


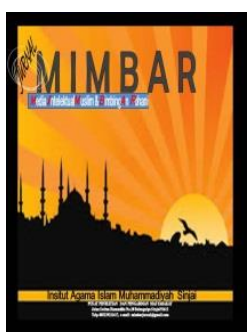

Jurnal Media Intelektual Muslim dan Bimbingan Rohani

Volume 5, No. 2, 2019

ISSN (print) : 2442-3217

ISSN (online) : 2716-3806

Homepage : http://journal.iaimsinjai.ac.id/indeks.php/mimbar

mengatakan pendapat yang sebaliknya, "Iman adalah ma'rifatullah (mengenai Allah), tunduk, dan cinta kepada-Nya dengan hati. Murjiah diambil dari al-irja, yaitu menunda, menangguhkan, mengakhirkan: mungkin karena mereka mengakhirkan tingkatan amal dari iman. Hakikat terakhir yang pantas untuk diketahui tentang mazhab ini adalah bahwa ia adalah mazhab agamis filosofis. Objeknya membahas hakikat iman dan hubungan amal dengannya, dari segi teoritis semata, sama seperti mazhab Muktazilah dalam periode lahirnya. ${ }^{45}$

Aliran teologi al-Murji'ah sebagaimana juga al-Khawarij, pada mulanya juga ditimbulkan oleh kasus politik, tegasnya persoalan khilafah yang membawa perpecahan dikalangan umat Islam setelah Utsman bin Affan mati terbunuh. ${ }^{46}$ Golongan Murji'ah merupakan golongan memiliki sikap netral dan memiliki pandangan bahwa setiap persoalan yang dilakukan oleh umat Islam atau golongan-golongan lainnya-lebih baik menundanya penyelesaian sampai persoalan mereka kepada Tuhan di akhirat nanti.

Dalam pandangan Murjiah pada bidang teologi, pemikiran mereka cenderung mengacu kepada permasalahan iman, kufur, dosa besar, dosa ringan, tauhid, tafsir AlQur'an, eskatologi, pengampunan atas dosa besar, kemaksuman nabi, ada yang kafir di generasi awal islam, tobat, hakekat Al-Qur'an, nama dan sifat Allah, serta ketentuan tuhan. Murji'ah memiliki empat ajaran pokok, yaitu: (1), Menunda hukuman atas Ali, Mu'awiyah, Amr bin Ash, dan Abu Musa Al-Asy'ari yang terlibat tahkim dan menyerahkannya kepada Allah di hari kiamat kelak. (2), Menyerahkan keputusan kepada Allah atas orang muslim yang berdosa besar. (3), Meletakkan (pentingnya) iman dari amal. (4), Memberikan pengharapan kepada muslim yang berdosa besar untuk memperoleh ampunan dan rahmat dari Allah. Inti faham atau doktrindoktrin Murji'ah adalah sebagai berikut :

Iman ialah mengenal Allah dan Rasulnya, barangsiapa yang tidak mengenal bahwa "tidak ada Tuhan selain Allah dan Muhammad sebagai Rasul-Nya", ia mukmin sekalipun melakukan dosa.

${ }^{45}$ Muhammad Dhiauddin Rais, Teori., hlm. 54-55.

${ }^{46}$ M. Amin Nurdin dan Afifi Fauzi Abbas, Sejarah Pemikiran Islam, Teologi-Ilmu Kalam, (Jakarta: Amzah, 2011), hlm. 23, 


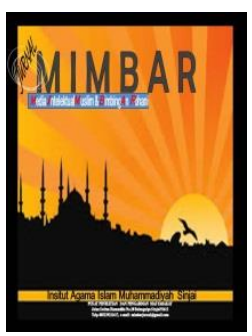

Jurnal Media Intelektual Muslim dan Bimbingan Rohani

Volume 5, No. 2, 2019

ISSN (print) : 2442-3217

ISSN (online) : 2716-3806

Homepage : http://journal.iaimsinjai.ac.id/indeks.php/mimbar

Amal perbuatan bukan merupakan bagian dari iman, sebab iman adanya dalam hati.

Sekalipun melakukan dosa besar, tidaklah akan menghapus iman seseorang, tetapi terserah Allah untuk menentukan hukumnya ${ }^{47}$

\section{Analisis Evolusi Teori Politik Islam dari Era Kenabian, Sahabat Hingga Sekte- Sekte Islam}

Dari sketsa historisitas kelahiran teori-teori politik Islam sejak era kenabian hingga mengalami evolusi pada masa sahabat-kekhalifahan para khulafa Al-Rasyidun dan melahirkan partai-partai (sekte-sekte) yang membawa kecenderungan memiliki pemikiran politik yang berbeda. Dari sepanjang sejarah itu hingga seperti yang kita kenal pada masa kini dunia Islam dengan ragam corak pemikiran kelompok-kelompok Islam yang ada dan bahkan seolah memunculkan teori politik baru adalah sebuah implikasi dari historis teori politik Islam masa lalu, hal ini tidak dapat disangksikan sebagai sebuah evolusi dari teori poltik Islam.

Evolisi pemikiran teori politik Islam tersebut, dalam analisa penulis hal ini dilatarbelakangi dan berimplikasi pada beberapa hal yaitu;

Pertama, pada era kenabian aspek penyebaran agama Islam yang dilakukan oleh Nabi SAW masih sangat labil ditengah pengaruh dan tantangan intimidasi kaum Kafir Quraisy, era kenabian merupakan tantangan awal dalam penyebaran Islam hal ini mengindikasikan bahwa Nabi telah menyusun strategi dakwah penyebaran Islam untuk menghindari tekanan yang berlebihan dari kaum Kafir Quraisy terhadap pengikut Nabi, melakukan hijrah ke kota Madinah merupakan langkah perpolitikan dalam rangka mengembang risalah penyebaran agama Islam.

Kedua, Langkah perpolitikan yang dipraktekkan oleh Nabi SAW pasca hijrahnya ke kota Madinah Al-Munawarah memberikan nuangsa demokratis bagi umat Islam dan umat agama lain. Memberikan kebebasan hidup beragama tanpa paksaaan dan intimitasi terhadap agama tertentu. Potret politik yang hadir tengah negara Islam Madinah membawa pada kondisi kehidupan beragama yang harmonis dan patuh pada pemimpin yang satu di

${ }^{47}$ Irfan Syam, Pemikiran Khawarij dan Al-Murjiah, dalam website, http://irfansyamd.blogspot. com/2012/05/pemikiran-al-khawarij-dan-al-murjiah.html, di Akses, 24 Maret 2013. 


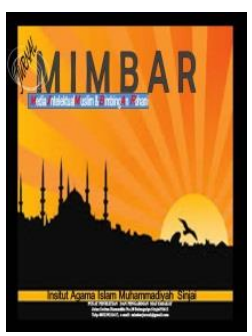

Jurnal Media Intelektual Muslim dan Bimbingan Rohani

Volume 5, No. 2, 2019

ISSN (print) : 2442-3217

ISSN (online) : 2716-3806

Homepage : http://journal.iaimsinjai.ac.id/indeks.php/mimbar

bawah bendera sehingga memberikan inspirasi bagi pemimpin-pemimpin Islam di masamasa selanjutnya.

Ketiga, Madinah dalam potret sejarah dengan kehadiran agama Islam menampilkan corak negara Islam pertama dengan politik Islam di dalamnya membawa pada sebuah eksperimen tunggal yang sulit terulang pada masa kini.

Keempat, teori-teori politik Islam yang ditularkan Nabi kepada para sahabat membawa inspirasi dalam mengembang amanah penyebaran Islam sebagai rahmatan lilalamin, pengembangan dan penyebaran agama Islam dengan melalui politik sangat mempengaruhi perkembangan agama Islam ke berbagai wilayah, politik Islam dengan pendekatan persaudaraan sebagai asas utama dan mendasari pemerintahan dan hubungan antar pemimpin Islam terhadap pemimpin suku atau negara lain.

Kelima, dalam masa pemerintahan para khalifah Al-Rasyidun memiliki tantangan dari beberapa kelompok masyarakat Islam yang memiliki kecenderungan kontra pemerintah, cenderung revolusioner dan memunculkan ketidakpuasan suatu golongan terhadap khalifah. Hal ini memberikan pengaruh luar biasa terhadap perkembangan perpolitikan dalam Islam, ketidakpuasan suatu komunitas Islam terhadap kelompok lain atau pemerintahnya melahirkan efek dan sekat yang berkepanjangan hingga memunculkan teori-teori politik.

Keenam, perbedaan kemampuan para pemimpin Islam dalam memimpin negara atau suatu wilayah dan ummat Islam yang tersebar luas sehingga melahirkan potensi kelompok tertentu untuk membesarkan dan mengembangkan ideology dan politiknya. Membangun dan memobilisasi kelompok dengan memiliki pandangan terhadap dunia Islam yang mempengaruhi berbagai bidang kehidupan ummat Islam pada umumnya.

Ketujuh, cita-cita pemimpin Islam melalui penyebaran agama Islam (ekspansi) ke berbagai wilayah di dunia membawa pengaruh pada kelompok tertentu untuk merumuskan teori-teori politik. Seiring dengan perkembangan Islam dan kualitas pemimpin Islam yang berbeda dari masa kemasa dengan dinamika serta tantangan dalam pemerintahan serta karakter masyarakat yang dihadapinya sangat beragam dan kian kompleks. 


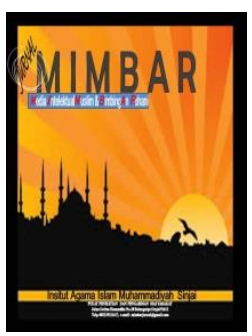

Jurnal Media Intelektual Muslim dan Bimbingan Rohani

Volume 5, No. 2, 2019

ISSN (print) : 2442-3217

ISSN (online) : 2716-3806

Homepage : http://journal.iaimsinjai.ac.id/indeks.php/mimbar

Evolusi pemikiran politik tersebut sangat berpengaruh terhadap perkembangan dan perpolitikan dunia masa kini dimana dalam konteks kekinian perpolitikan kadang diidentikan sebagai alat kehausan untuk mencapai tujuan yang secara tidak langsung meruntuhkan nilai, merendahkan dan bahkan melenyapkan suatu individu dan atau kelompok tertentu, potret inilah yang sangat urgen dijadikan sebagai landasan konstruktif dengan menarik konsep dan teori politik Islam yang disketsakan sejarah sejak era kenabian dan sahabat kedalam era kekinian yang tanpa kehilangan ruh dan asas Islami atau tidak terlepas dari nilai-nilai fundamental Islam.

\section{N. Kesimpulan}

Kesempurnaan era kenabian merupakan ciri utama yang nampak dan membawa perubahan sosial pada masyarakat Arab umumnya. Dalam pembentukan negara Islam-negara Madinah, Nabi SAW telah menerapkan politik Islami sehingga negara yang dipimpinnya mendapat pengakuan dari musuh-musuh Islam (kaum Kafir Quraisy) bahkan dunia. System pemerintahan demokratis negara Madinah merupakan sebuah eksperimen tunggal yang belum pernah berulang pada pemerintahan hingga masa kini.

Politik Islam adalah suatu alat atau strategi yang digunakan untuk mencapai tujuan inti dalam suatu pemerintahan dalam kenegaraan yang berasaskan nilai-nilai transedental dan syariah Islam. System terbentuknya kekhalifahan bermula dari penunjukan Abu Bakar menjadi khalifah pada pertemuan Saqifah. Hasil pertemuan ini sebagai salah satu sejarah penting dalam Islam sebagai kelanjutan kepemimpinan Rasulullah dalam pemerintahan Islam.

Sejarah kelahiran sekte-sekte dan teori-teori Islam bermula dari masa-masa akhir kekhalifahan Utsman bin Affan, corak pemerintahannya yang banyak membawa polemik internal Islam mulai melahirkan kelompok-kelompok gerakan yang anti pemerintahan hingga hal ini berlanjut dan mencapai puncaknya masa kekhalifahan Ali Bin Abi Thalib dengan melalui pertentangan Ali dan Mua'wiyah hingga menyebabkan kematian khlaifah Ali pasca peristiwa tahkim, polemik dan perpecahan ummat Islam ini diperparah dengan lahirnya sekte-sekte Islam seperti Syiah Khawarij, Mu’tazilah, Ahlu Sunnah, Murjiah yang 


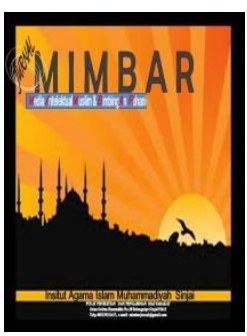

\section{MIMBAR}

Jurnal Media Intelektual Muslim dan Bimbingan Rohani

Volume 5, No. 2, 2019

ISSN (print) : 2442-3217

ISSN (online) : 2716-3806

Homepage : http://journal.iaimsinjai.ac.id/indeks.php/mimbar

masing memiliki ideologi dan pemikiran politik yang sangat berpengaruh pada perkembangan Islam pada tahap selanjutnya.

Masa keemasan pemerintahan yang dicontohkan Nabi ketika di Madinah melalui praktek politiknya yang Islami terus mengalami evolusi-politik baik dari kekhalifahan pertama hingga khalifah terakhir dan bahkan mengalami puncak evoluisi politik ini dengan lahirnya sekte-sekte Islam, hal ini dipengaruhi dan mempunyai latarbelakang yang berbeda.

Dengan pembaiatan Mua'wiyah sebagai khalifah akibat dari kegagalan peristiwa tahkim yang merugikan pihak Ali merupakan partai politik pertama yang muncul dalam sejarah ummat Islam. Pasca kekhalifahan para khulafa Al-Rasyidin (akhir pemerintahan Ali bin Abi Thalib) memulai babak baru sejarah Islam yang berbeda-beda dengan lahirnya sekte-sekte Islam. sekte-sekte Islam yang lahir yaitu Khawarij, Syiah, Mu'tazilah, Ahlul Hadis dan Sunnah dan Murjiah. Masing-masing sekte Islam ini memiliki peta pemikiran politik yang berbeda-beda dan dipengaruhi oleh berbagai alasan yang kuat sehingga tidak heran jika perbedaan pemikiran politik mereka menjadikan umat Islam tersekat dalam tradisi perpecahan politik, teori-teori politik yang muncul sebagai evolusi kritisisme yang membawa pengaruh luar biasa dalam sepanjang sejarah Islam hingga masa sekarang ini.

\section{DAFTAR PUSTAKA}

Ahmad, Mumtaz, Masalah-Masalah Teori Politik Islam, Bandung: Penerbit Mizan, 1996.

Albana, Jamal, Runtuhnya Negara Madinah (Islam Kemasyarakatan versus Islam Kenegaraan), terj. Jamadi Sunardi dan Abdul Mufid, edt. Khotimatul Husna, Yogyakarta: Pilar Media, 2005.

Alyah, Hamiyatul, Sketsa Historis Politik Islam Masa al-Khulafa al-Rasyidun, dalam Sejarah Politik Islam (Panggung Pergulatan Politik Kekuasaan dari Timur Tengan Hingga Asia, Yogyakarta: Nusantara Press, 2011.

Ana Retnoningsih, dan, Suharso, Kamus Besar Bahasa Indonesia, Edisi Lux, Semarang: Widia Karya, 2011. 


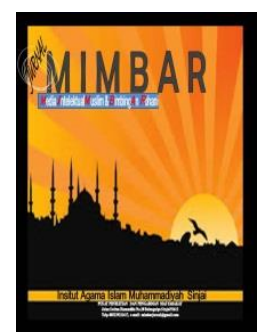

\section{MIMBAR}

Jurnal Media Intelektual Muslim dan Bimbingan Rohani

Volume 5, No. 2, 2019

ISSN (print) : 2442-3217

ISSN (online) : 2716-3806

Homepage : http://journal.iaimsinjai.ac.id/indeks.php/mimbar

Asbahri, Alfajri, dkk, Teori Politik Islam, dalam pdf. Tugas Makalah PAI, Bandung: Institut Tekhnologi Bandung, 2011.

Azra, Azyumardi, dkk, Artikulasi Islam Kultural (Dari Tahapan Moral ke Periode Sejarah), Edt. Asep Gunawan, Jakarta: PT. Raja Grafindo Persada, 2004.

Esposito, L., John, Islam Kekuasaan Pemerintahan, Doktrin Iman dan Realitas Sosial, terj. M.Khoirul Anam, Jakarta: Inisiasi Press, 2004.

Fachruddin, Mohd., Fuad, Pemikiran Politik Islam, Jakarta: Pedoman Ilmu Jaya, 1998.

Hamid, Qadir, Abdul, Tijani, Pemikiran Politik dalam Al-Qur'an, Terj. Abu Hayyi AlKattani, Jakarta: Gema Insani Press, 2001.

Karim, Abdul, M., Sejarah Pemikiran dan Peradaban Islam, Yogyakarta: Bagaskara, 2012.

Hamzah, Muchotob, Menjadi Politisi Islami (Fikih Politik), Yogyakarta: Gama Media, 2004.

Maryadi, eds, Telaah Kritis tentang Keadilan Para Sahabat dan Referensi Politik dalam Islam, Surakarta, Muhammadiyah University Press, 2002.

Muhamamad, Ali, Rusjdi, Politik Islam, Sebuah Pengantar, Yogyakarta: Pustaka Pelajar kerja sama BDI PT. Arun BDI PIM dan Yasat, 2000.

Nurdin, Amin, M. dan Abbas, Fauzi, Afifi, Sejarah Pemikiran Islam, Teologi-Ilmu Kalam, Jakarta: Amzah, 2011.

Rais, Dhiauddin, Muhammad, Teori Politik Islam, terj. Abdul Hayyie al-Kattani dkk, Jakarta: Gema Insani Press, 2001.

Salim, Muin, Abdul, Fiqh Siyasah, Konsepsi Kekuasaan Politik dalam Al-Qur'an, Jakarta: Raja Grafindo Persada, 2002. 


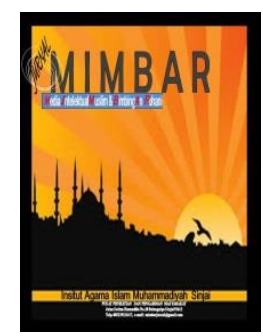

\section{MIMBAR}

Jurnal Media Intelektual Muslim dan Bimbingan Rohani

Volume 5, No. 2, 2019

ISSN (print) : 2442-3217

ISSN (online) : 2716-3806

Homepage : http://journal.iaimsinjai.ac.id/indeks.php/mimbar

Sawiy, Yujah, Khairuddin, Perebutan Kekuasaan Khalifah, (Menyingkap Dinamika dan Sejarah Politik Kaum Sunni), Yogyakarta: Safiria Insania Press, 2005.

Syam,Irfan, Pemikiran Khawarij dan Al-Murjiah, dalam Website, http://irfansyamd. blogspot. com /2012/05/pemikiran-al-khawarij-dan-al-murjiah. html.

Watt, Montgomery, W. Politik Islam dalam Lintasan Sejarah, terj. Helmy Ali, Muntaha Azhari, Jakarta: Perhimpunan Pengembangan Pesantren dan Masyarakat (P3), 1988.

Yatim, Badri, Sejarah Peradaban Islam, Jakarta: PT Raja Grafindo Persada, 1998. 